\title{
Genotype x Environment Interaction for Seed Yield and Protein Content in Fieldpea Genotypes under Kashmir Conditions
}

\author{
Asma Majid ${ }^{1}$, S.A. Dar ${ }^{2}$, Shabir H. Wani ${ }^{3}$, M.A. Bhat ${ }^{1}$, V.K. Ambardar ${ }^{2}$ and A.A. Lone ${ }^{2}$ \\ ${ }^{1}$ Division of Genetics and Plant Breeding, FoA, Wadura, Sopore -193201, \\ SKUAST-K, Jammuand Kashmir, India \\ ${ }^{2}$ DARS, Budgam, SKUAST-K, P.O Rangreth, Srinagar-191132, Jammu and Kashmir, India \\ ${ }^{3}$ Mountain Research Centre For Field Crops, Khudwani Anantnag-192101, Sher-e-Kashmir \\ University of Agricultural Sciences and Technology of Kashmir, J\&K, India \\ *Corresponding author
}

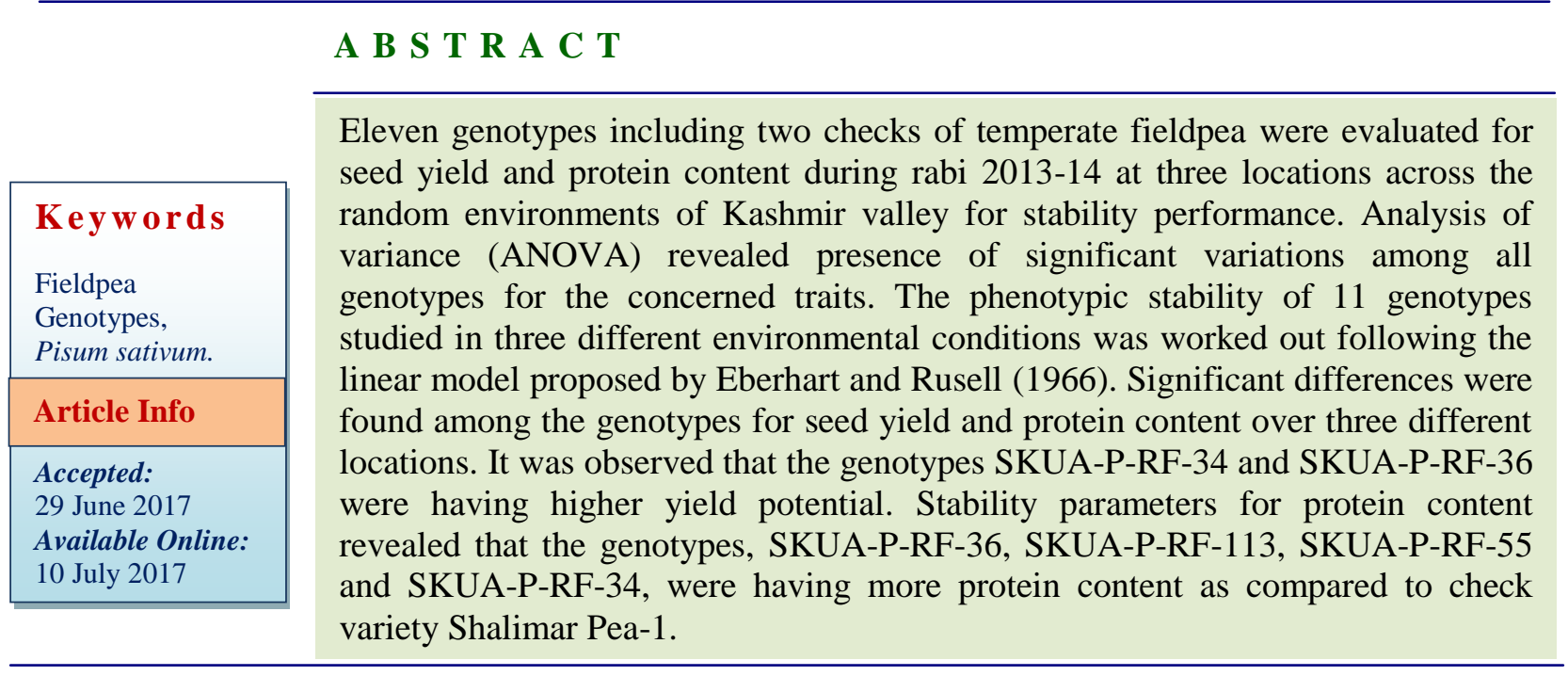

\section{Introduction}

Legumes being the third largest family of higher plant include 20,000 species and are second in agricultural importance based on area and total production (Graham and Vance, 2003). Pulses are an important crop for food security worldwide, and are important to the livelihood of millions of people, especially in the developing countries, wherefrom they derive their production, household food, animal feed, and income and form a unique feature of farming system, particularly in dryland agriculture. Protein malnutrition is prevalent among men, women and children in
India. Pulses contribute $11 \%$ of the total intake of proteins in India (Reddy, 2010). In India pulses are consumed in much higher quantity than that of other sources of protein, depicting the importance of pulses crop in Indian diet. Being the cheapest source of protein, it is important to enhance production of pulses in order to obtain balanced diet among the socially and economically backward classes.

Fieldpea (Pisum sativum L.) belongs to genus Pisum, family Papilionaceae with 
chromosome number $(2 \mathrm{n}=14)$. It is an important rabi pulse crop because of its higher yield potential and is grown for food, feed and vegetable. So far the nutritional aspect of fieldpea is concerned, it is high protein crop with all the essential amino acids, lysine and tryptophan, important for normal activity of living organisms which are usually low in cereal grains. Consequently, it can supplement the low amount of protein present in food processed from cereal grains (Oelke et al., 1991). It is low in fibre and contains 86$87 \%$ of total digestible nutrients, which makes it an excellent livestock feed. The pea had been used as a good source of nutritious food since Neolithic times. Globally pea is second largest food legume after dry beans and is one of the earliest human foods. It is cultivated in about more than 50 countries in the arid, semi-arid and temperate regions. About $90 \%$ of world fieldpea is grown under rainfed conditions and is cultivated in an area of about 2.1 million ha with production of 16 million tonnes (FAO STAT, 2011). India grows fieldpea in an area of about 0.76 million has and production of about 0.84 million tonnes with an average productivity of 1100 $\mathrm{kg} \mathrm{ha}{ }^{-1}$ (Anonymous, 2013).It is mainly cultivated in UP, MP, Bihar, Assam, Maharashtra and Rajasthan. In Jammu \& Kashmir state, pulses are cultivated over an area of about 30 thousand ha with a production of about 170 thousand quintals and productivity of about $5.6 \mathrm{q} \mathrm{ha}{ }^{-1}$ (Anonymous, 2012). Initially plant breeding programs were mostly focused on developing high yielding varieties. But now importance is given to develop stable and sustainable yields under various environmental conditions. The development of crop varieties, which are being adapted to wide range of fluctuating environments, is the ultimate goal of plant breeders in crop enhancement program (Muhammad et al., 2003).Genotype x environment interaction is an important issue for breeders, in order to develop a novel variety from other environment. A variety is considered to be more stable if it has a high mean yield but a low degree of fluctuation in yielding ability when planted over diverse environments (Purchase, 1997). The present investigation was carried out to measure the genotype environment interaction in field pea genotypes giving emphasis to grain yield and protein content. In order to diversify the varietal profile of fieldpea in the valley, it is necessary to identify and evolve more number of genotypes possessing high production potential and better quality through the application of a sound breeding programme. For such an effort to be successful, estimation of the nature and magnitude of genetic variability is very essential. This genetic variability becomes meaningful only when a large number of germplasm lines are systematically evaluated under a set of randomly selected environments so as to have nearly unbiased estimates of genetic parameters. Stable and high yielding genotype is among the main objectives of field pea breeding, particularly adaptation to short growing season (Khan et al., 1996). Stability performance of genotypes will be of special importance in Jammu and Kashmir where environmental conditions vary considerably and the means of modifying the environment are inadequate.

\section{Materials and Methods}

The present investigation was carried at three random locations during rabi 2013-14. The three random locations were i) Urban Technology Park-Habak, (Srinagar), ii) Dryland (Karewa) Agriculture Research Station (Budgam), and iii) Krishi Vigyan Kendra-Malangpura (Pulwama).Eleven genotypes were sown in randomized complete block design (RCBD) with three replications at each locations. Each experimental plot consisted of 3 rows of $3 \mathrm{~m}$ length. The inter and intra- row spacing was maintained at 30 
and $10 \mathrm{~cm}$ respectively. Uniform standard plant population was maintained. Recommended packages of practices were adopted to raise a good crop. Observations were recorded on the various yield and quality traits at the appropriate developmental stages of plant growth and morphological characters. The phenotypic stability of 11 genotypes [SKUA-P-RF-49,SKUA-P-RF-36,SKUA-PFP-113,SKUA-P-RF-113,SKUA-P-RF55,SKUA-P-RF-34,SKUA-P-RF-94,SKUAP-RF-31,SKUA-P-RF-107, Shalimar Pea1, Rachna] studied in three different environmental conditions was worked out following the linear model proposed by Eberhart and Rusell (1966). The genotypes were collected from Dryland (Karewa) Agriculture Research Station (Budgam). For analyzing the results window stat software was used. The seed yield obtained from selected plants from each experimental plot was weighed and averaged to single plant basis in grams. Protein content (\%) was calculated by using nuclear resonance machine, three samples were drawn randomly from each plot and average worked out for each replication.

\section{Results and Discussion}

A variety can be considered stable across environments if it has high mean yield, unit regression and least deviation around the regression slope (Eberhart and Russell, 1966). Although there are many stability parameters, Eberhart and Russell (1966) model's parameter $S^{2} d_{i}$ appeared to be very important. Since the variance of $S^{2} d_{i}$ is a function of number of environments hence several environments with minimum replications per environment are advocated to be necessary to obtain reliable estimates of $\mathrm{S}^{2} \mathrm{~d}_{\mathrm{i}}$. Variance due to genotypes $\times$ environments $(\mathrm{G} \times \mathrm{E}$ interaction) revealed significant differences for the traits revealing that the genotypes were having, by and large, significant differential response to the changing environments.
Component analysis of the environments + genotype $\times$ environment interaction $[\mathrm{E}+(\mathrm{G} \times$ E)] was significant for the concerned traits. Similarly, partitioning of this variation into linear and non-linear components revealed that the mean squares due to environments (linear) were highly significant for the traits. The significant mean squares confirmed that the environments were random and different and they exercised influence on the expression of a trait. This variation could be attributed to have arisen due to linear response of the regression of the genotypes to the environment. The mean squares due to $G$ $\times \mathrm{E}$ (linear) were significant for all the traits revealing that behaviour of the genotypes could be predicted more precisely over environments. This can be efficiently used for identifying the suitable genotype for a particular area (Table 1).

The non-linear component arising due to heterogeneity, measured as mean squares due to pooled deviation was significant for the concerned traits. These significant mean squares revealed presence of non-linear response of the genotypes to the changing environments (stability performance). The significant mean squares for pooled deviation confirmed contribution of non-linear component to total $\mathrm{G} \times \mathrm{E}$ interaction.

The genotypes differed with respect to the stability for these traits making its prediction more difficult. However, comparing the magnitude of the linear component with that of non-linear component of mean squares it was observed that the linear component i.e. environment (L) and genotype $\times$ environment (L) was many times higher than the non-linear component (pooled deviation) for all the traits. These traits displayed significant linear and non-linear component however, the relative magnitude of the linear component was many times higher than that of the nonlinear component. 
Table.1 Analysis of variance for seed yield and protein content in fieldpea (Pisum sativum L.) genotypes across random environments

\begin{tabular}{|c|c|c|c|}
\hline \multirow[t]{2}{*}{ Source of variation } & & Mean squares & \\
\hline & d.f. & Seed yield plant $^{-1}(\mathrm{~g})$ & Protein content $(\%)$ \\
\hline Genotypes & 10 & $12.559 * *$ & $1.009 * *$ \\
\hline $\begin{array}{l}\text { Environment }+ \text { (genotype } \times \\
\text { environment) }\end{array}$ & 22 & $1.464 *$ & $0.586 * *$ \\
\hline Environments & 2 & $7.528 * *$ & $2.120 * *$ \\
\hline Genotype $\mathrm{x}$ environments & 20 & $1.027 *$ & $0.258 * *$ \\
\hline Environments (linear) & 1 & $15.164 * *$ & $4.241 * *$ \\
\hline $\begin{array}{l}\text { Genotype x environment } \\
\text { (linear) }\end{array}$ & 10 & $1.277 *$ & $0.487 *$ \\
\hline Pooled deviation & 60 & $0.288 *$ & $0.100 * *$ \\
\hline Pooled error & 32 & $12.559 * *$ & $1.009 * *$ \\
\hline
\end{tabular}

*Significant at $\mathrm{p} \leq 0.05 ; \quad * *$ Significant at $\mathrm{p} \leq 0.01$

It revealed that prediction of stability could be reliable, though it may get affected to some extent. For seed yield plant $^{-1}$ (g) genotypes SKUA-P-RF-36 and SKUA-P-RF-34 were found to have highest yield. For protein content $(\%)$ promising genotypes found were SKUA-P-RF-49, SKUA-P-RF-36, SKUA-PRF-113, SKUA-P-RF-55, SKUA-P-RF-34 and SKUA-P-RF-94.

Considering their mean performance and the average stability into consideration, it could be derived that SKUA-P-RF-34 and SKUA-PRF-36 were well adapted to the entire environment. Mean performance for seed yield plant ${ }^{-1}$ was observed higher in SKUA-PRF-34 which was more than $38 \%$ against the check Shalimar Pea-1. Stability parameters for protein content revealed that the genotypes, SKUA-P-RF-36, SKUA-P-RF113, SKUA-P-RF-55 and SKUA-P-RF-34, were having more protein content as compared to the check variety Shalimar Pea1 .

\section{References}

Anonymous. 2012. Digest of Statistics. Directorate of Economics and Statistics,
J\&K Government, p. 89.

Anonymous. 2013. Project Coordinator's Report, AICRP on MULLaRP, IIPR, Kanpur, pp.17.

Eberhart, S.A. and Russell, $\quad$ W.A. 1966. Stability parameters for comparing varieties. Crop Sci., 6: 36-40.

FAO. 2011. FAOSTAT (www.faostat.org).

Graham, P.H. and Vance, C.P. 2003. Legumes: Importance and constraints to greater use. Plant Physiol., 131: 872877.

Khan, T.N., French, R.J. and Hardie, D.C. 1996. Breeding fieldpeas for Western Australia: Progress and problems. Pisium Genetics, South Perth, Australia, 28: 5-12.

Muhammad, A., Ahmad, B., Haqqani, A. and Muhammad, B. 2003. Genotype environment interaction for grain yield in chick pea (Cicerarientinum L). Pak. J. Biol., 35(2): 181-186.

Oelke, E.A., Oplinger, E.S., Hanson, C.V., Davis, D.W., Putnam, D.H., Fuller, E.I. and Rosen, C.J. 1991. Dry Field Pea: Alternative Crops Manual. University of Wisconsin-Extension, University of Minnesota-Center for Alternative Plant and Animal Products and the Minnesota 
Extension Service, St. Paul, Minnesota.

Purchase, J.L. 1997. Parametric stability to describe G XE interactions and yield stability in winter wheat, $\mathrm{PhD}$. Thesis, Department of Agronomic, Faculty of Agri., Univ. of Orange Free state,
Bloemfontein, South Africa.

Reddy, A.A. 2010. Regional Disparities in Food Habits and Nutritional intake in Andhra Pradesh, India, Regional and Sectoral Economic Studies, Vol. 10-2.

\section{How to cite this article:}

Asma Majid, S.A. Dar, Shabir H. Wani, M.A. Bhat, V.K. Ambardar and Lone, A.A. 2017. Genotype x Environment Interaction for Seed Yield and Protein Content in Fieldpea Genotypes under Kashmir Conditions. Int.J.Curr.Microbiol.App.Sci. 6(7): 3880-3884.

doi: https://doi.org/10.20546/ijcmas.2017.607.399 